
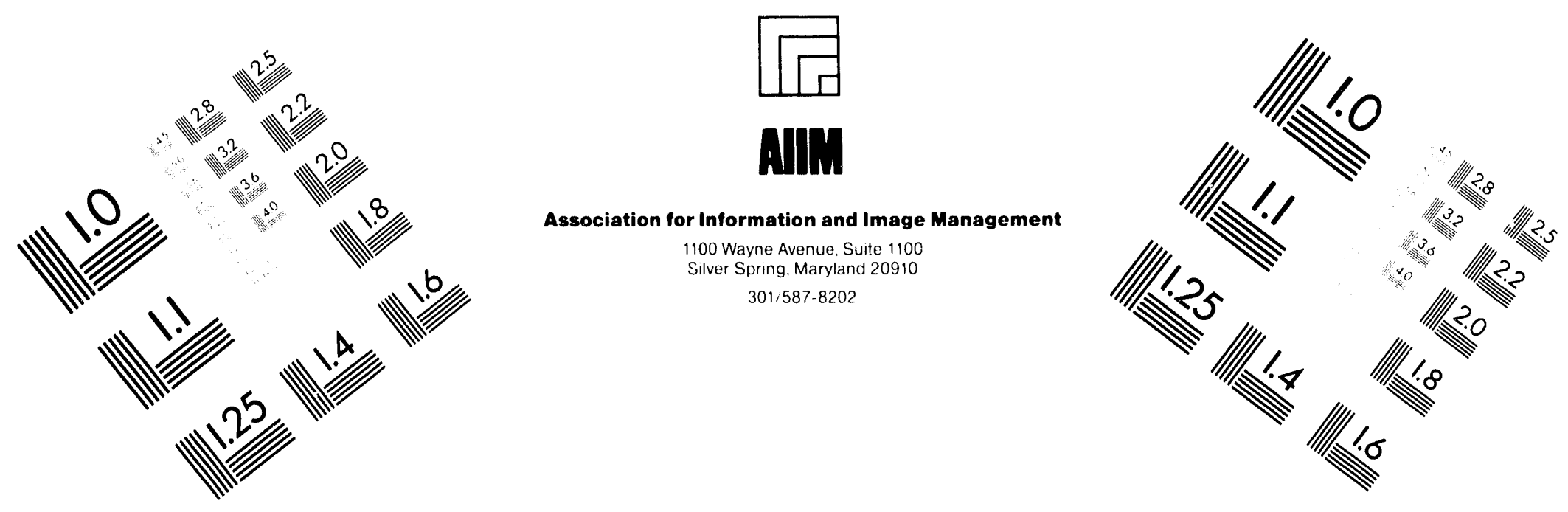

\title{
Centimeter
}

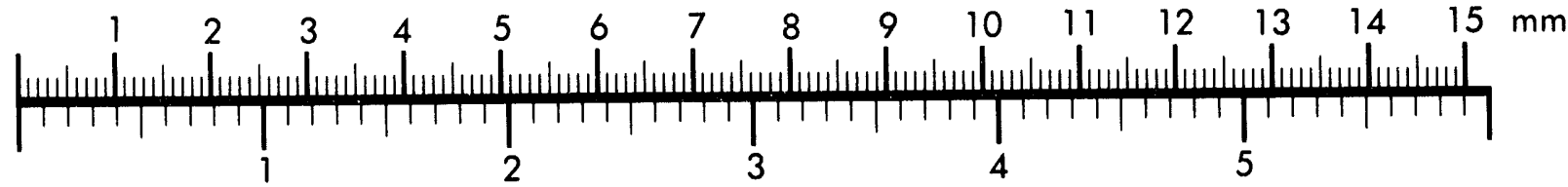

Inches
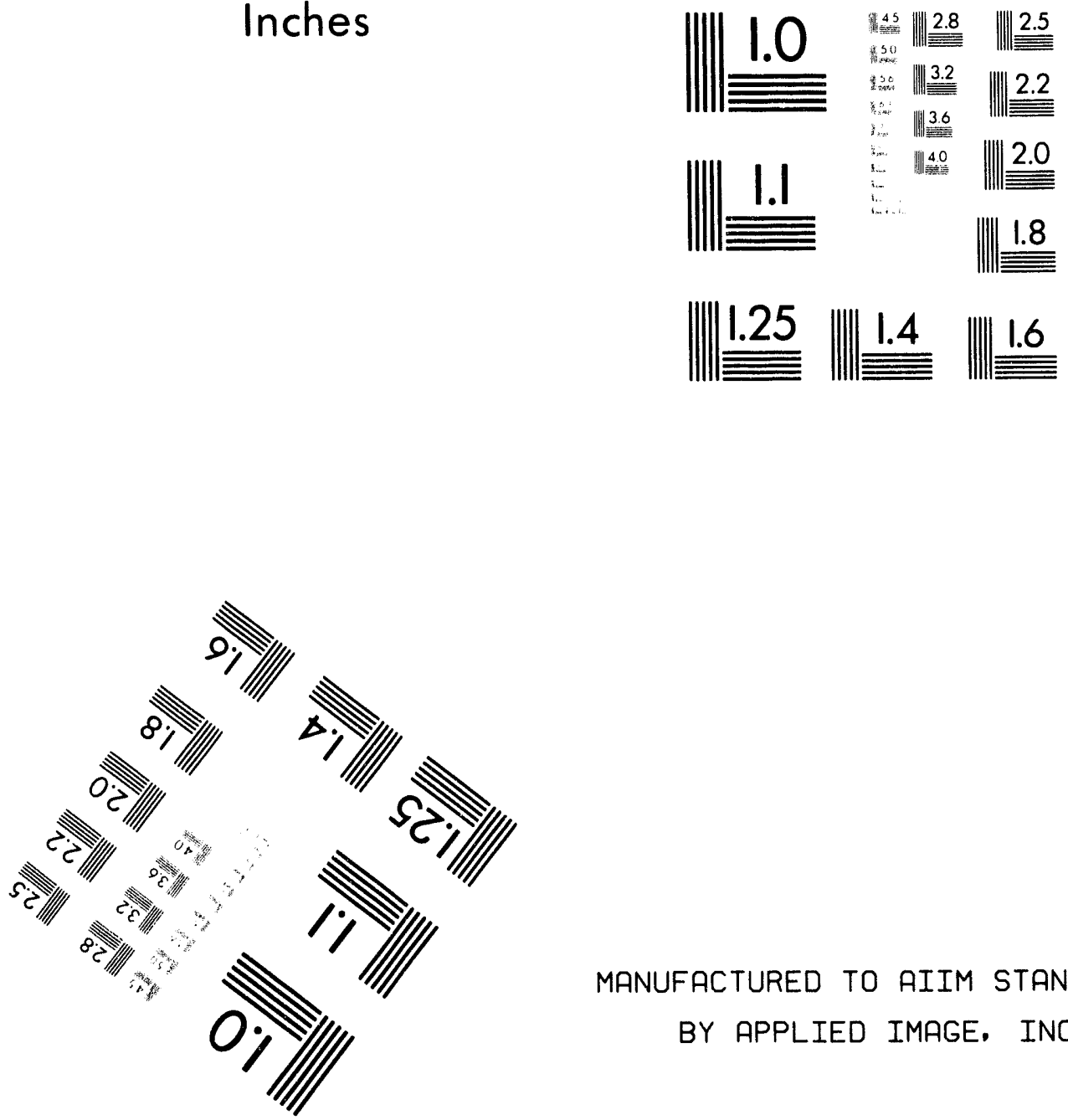

MANUFACTURED TO AIIM STANDARDS

BY APPLIED IMAGE, INC.

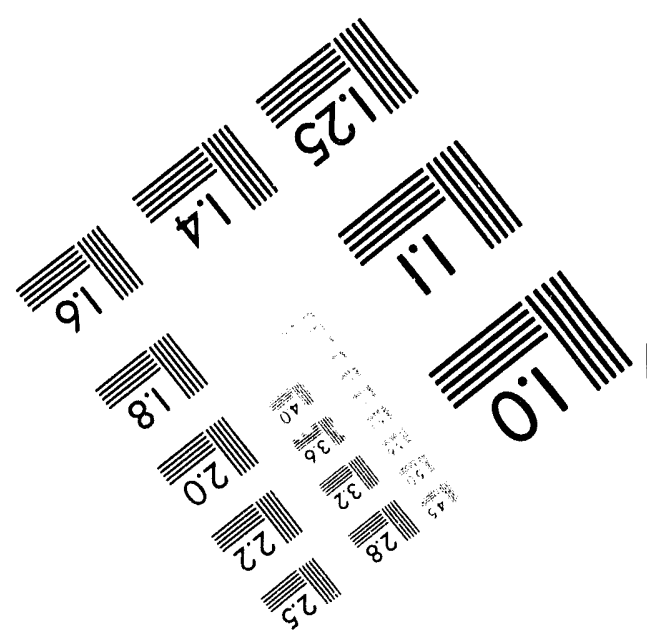



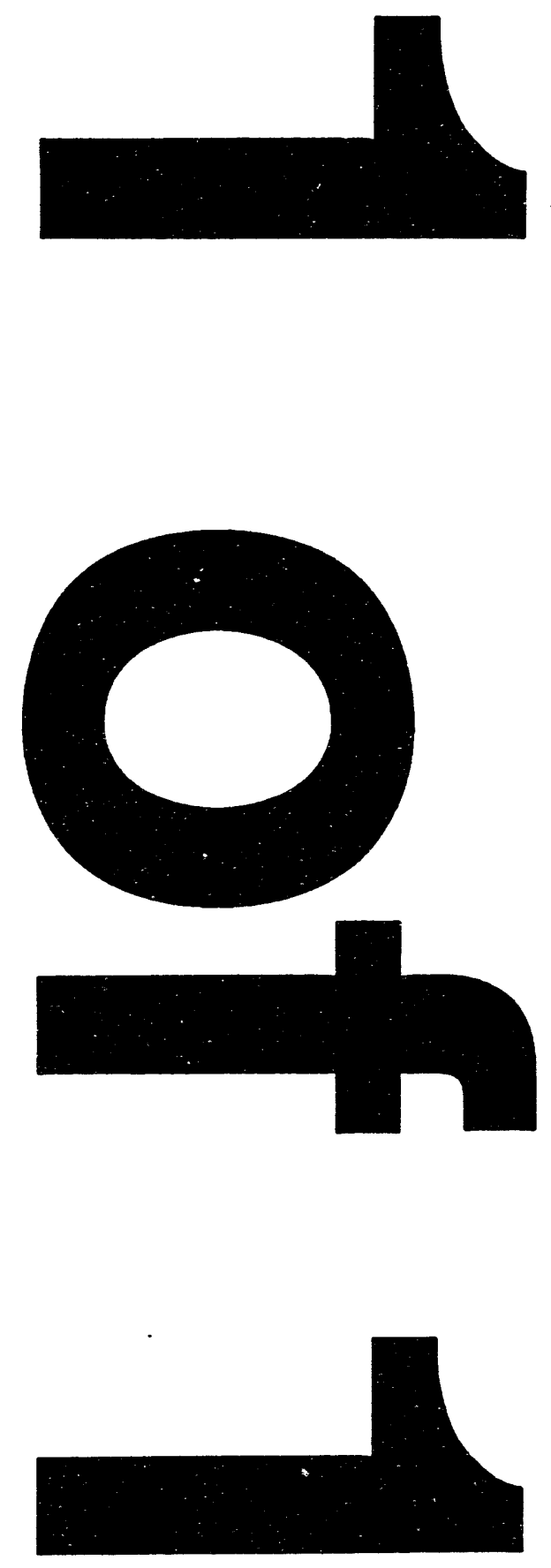


\section{Hanford Permanent Isolation Barrier Program: Asphalt Technology Test Plan}

H. D. Freeman

R. A. Romine

May 1994

Prepared for the

U.S. Department of Energy under

Contract DE-AC06-76RLO 1830

Pacific Northwest Laboratory Richland, Washington 99352 


\section{Summary}

The Hanford Permanent Isolation Barriers use engineered layers of natural materials to create an integrated structure with redundant (backup) protective features. The natural construction materials (e.g., fine soil, sand, gravel, riprap, asphalt) have been selected to optimize barrier performance and longevity. The objective of current designs is to develop a maintenance-free permanent isolation surface barrier that isolates wastes for a minimum of 1000 years by limiting water drainage to near-zero amounts; reducing the likelihood of plant, animal, and human intrusion; controlling the exhalation of noxious gases; and minimizing erosion-related problems. Asphalt is being used as an impermeable water diversion layer to provide a redundant layer within the overall barrier design. This redundancy ensures barrier compliance should a breach of the overlying earthen layers occur.

Data on asphalt barrier properties in a buried environment are not available for the required 1000-year time frame. The purpose of this test plan is to outline the activities planned to obtain defensible long-term asphalt barrier data through laboratory experiments and comparisons with natural analogs. These data will then be used to estimate performance of the asphalt layers over a range of potential disruptive events to ensure overall barrier compliance over the design life of the Hanford Permanent Isolation Barriers. Other information on application techniques and quality assurance/control procedures will also be addressed to determine if modifications to standard asphalt paving practices are necessary to ensure the asphalt barrier will meet the stringent performance objectives.

This test plan outlines the work to be conducted by Pacific Northwest Laboratory to meet these objectives. Work described in this test plan will be performed during a 4-year period beginning in FY 1994. The study is divided into the following activities:

1. Develop a defensible accelerated aging test procedure to allow measurements of asphalt barrier properties as a function of age for a minimum of 1000 years.

2. Age potential asphalt barrier materials over a range of conditions expected in the subsurface environment, including temperature, oxygen content, moisture, and the presence of gases or ions produced by the underlying soil and waste forms.

3. Measure the changes in fundamental asphalt barrier properties using standard and modified asphalt testing procedures to provide the database of information required to assess the longterm performance of the asphalt barrier system.

4. Supplement and validate the laboratory aging data by comparing with several-hundred- to several-thousand-year-old asphalt artifacts from Santa Barbara, California, and other archaeological sites.

5. Estimate the response of aged asphalt materials to a range of disruptive stresses such as subsurface subsidence and/or seismic events through computer simulations and limited laboratory and field tests. 
6. Evaluate the applicability of standard asphalt application techniques and quality assurance/control procedures to determine if they are adequate to ensure that the stringent barrier performance requireme-'s w'ill be met. 


\section{Abbreviations}

$\begin{array}{ll}\text { AAG-1 } & \text { AR-4000 graded asphalt } \\ \text { DOE } & \text { U.S. Department of Energy } \\ \text { EPA } & \text { U.S. Environmental Protection Agency } \\ \text { HDW-EIS } & \begin{array}{l}\text { Hanford Defense High-Level, Transuranic, and Tank Wastes Environmental } \\ \text { Impact Statement }\end{array} \\ \text { HMAC } & \text { hot-mix asphalt concretes } \\ \text { HDPE } & \text { high density poly(ethylene) } \\ \text { HPIB } & \text { Hanford Permanent Isolation Barriers } \\ \text { HPLC-SEC } & \text { high pressure liquid chromatography - size exclusion chromatography } \\ \text { IR } & \text { infrared spectroscopy } \\ \text { Ni/V } & \text { nickel/vanadium } \\ \text { RCRA } & \text { Resource Conservation and Recovery Act of 1976 } \\ \text { PNL } & \text { Pacific Northwest Laboratory } \\ \text { QA/QC } & \text { quality assurance/control } \\ \text { SHRP-MRL } & \text { Strategic Highway Research Program - Materials Reference Library } \\ \text { TFOT } & \text { thin film oven test } \\ \text { THF } & \text { tetrahydrofuran } \\ \text { UV } & \text { Westinghouse Hanford Company } \\ \text { WHC } & \end{array}$




\section{Contents}

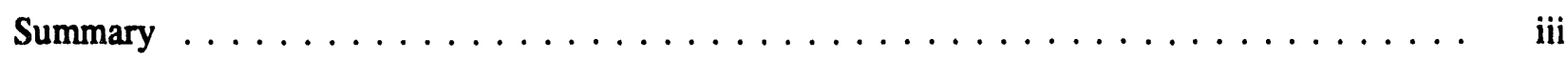

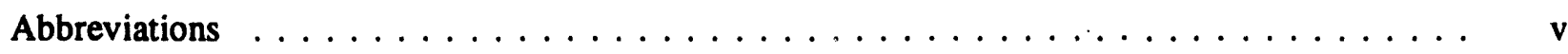

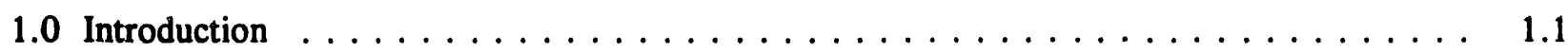

2.0 Hanford Permanent Isolation Surface Barrier $\ldots \ldots \ldots \ldots \ldots \ldots \ldots \ldots \ldots . .1$

2.1 The Need for Permanent Isolation Surface Barriers $\ldots \ldots \ldots \ldots \ldots \ldots \ldots 2.1$

2.2 Funztional Requirements for Permanent Isolation Surface Barriers $\ldots \ldots \ldots \ldots 2.2$

2.3 Role of Asphalt in the Permanent Isolation Surface Barrier $\ldots \ldots \ldots \ldots \ldots 2.3$

2.3.1 Historical Background $\ldots \ldots \ldots \ldots \ldots \ldots \ldots \ldots \ldots \ldots \ldots \ldots$

2.3.2 Composite Asphalt Barrier $\ldots \ldots \ldots \ldots \ldots \ldots \ldots \ldots \ldots \ldots .2 .4$

3.0 Asphalt Technology Development $\ldots \ldots \ldots \ldots \ldots \ldots \ldots \ldots \ldots \ldots \ldots \ldots \ldots \ldots$

3.1 Accelerated Aging Procedure Development $\ldots \ldots \ldots \ldots \ldots \ldots \ldots \ldots .1$

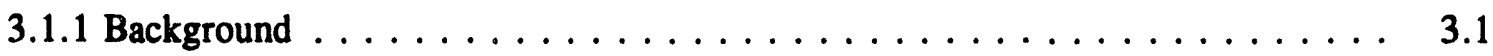

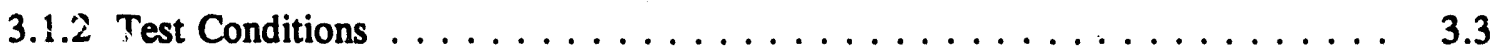

3.1.3 Analytical Techniques $\ldots \ldots \ldots \ldots \ldots \ldots \ldots \ldots \ldots \ldots \ldots \ldots \ldots$

3.1.4 Experimental Methods $\ldots \ldots \ldots \ldots \ldots \ldots \ldots \ldots \ldots \ldots \ldots . \ldots \ldots$

3.1.5 Asphalt Aging Conditions $\ldots \ldots \ldots \ldots \ldots \ldots \ldots \ldots \ldots \ldots .3 .8$

3.1.6 Physical Properties Tests $\ldots \ldots \ldots \ldots \ldots \ldots \ldots \ldots \ldots \ldots . .6 \ldots$

3.2 Asphalt Analogs $\ldots \ldots \ldots \ldots \ldots \ldots \ldots \ldots \ldots \ldots \ldots \ldots \ldots \ldots$

3.2.1 Background $\ldots \ldots \ldots \ldots \ldots \ldots \ldots \ldots \ldots \ldots \ldots \ldots \ldots, 3.9$

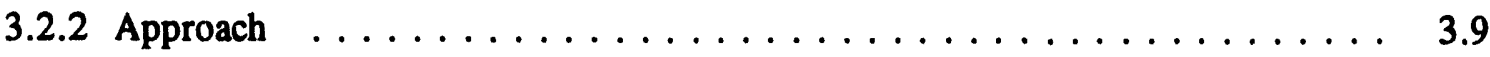

3.2.3 Chemical Analysis of Archaeological Asphalt to Determine
the Effects of Aging $\ldots \ldots \ldots \ldots \ldots \ldots \ldots \ldots \ldots \ldots \ldots \ldots$

3.2.4 Physical Testing of Aged Control Asphalt $\ldots \ldots \ldots \ldots \ldots \ldots \ldots . .13$ 
3.2.5 Obtaining Additional Analog Samples . . . . . . . . . . . . . . . . 3.14

3.3 Application Techniques and $\mathrm{QA} / \mathrm{QC}$ Issues $\ldots \ldots \ldots \ldots \ldots \ldots \ldots \ldots$

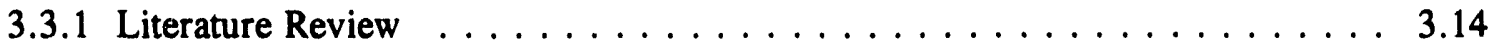

3.3.2 Discussions with Asphalt Application and Paving Contractors . . . . . . . . 3.14

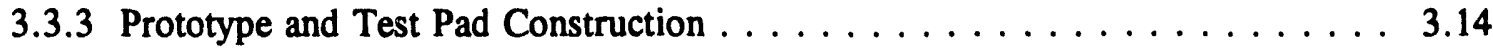

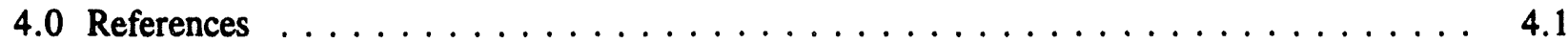




\section{Figures}

2.1 Conceptual Design of the Permanent Isolation Surface Barrier $\ldots \ldots \ldots \ldots \ldots$

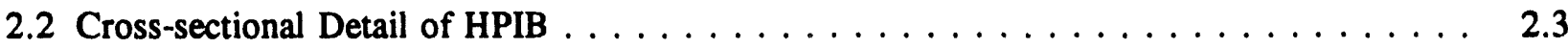

3.1 Geologic Structure of Petroleum Bearing Deposits Within the

Santa Barbara Channel Region . . . . . . . . . . . . . . . . . . 3.11

3.2 Santa Barbara Channel Area Showing Distribution of Asphalt-Containing

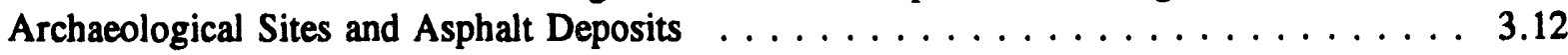

\section{Tables}

3.1 Experimental Conditions for FY 1994 Accelerated Aging Study . . . . . . . . . . . . . 3.4

3.2 Aggregate Gradation for Laboratory Mixture Samples $\ldots \ldots \ldots$ 


\subsection{Introduction}

The exhumation and treatment of hazardous, radioactive, or mixed wastes may not always be the preferred alternative in the remediation of a waste site. In-place disposal methods, under certain circumstances, may be the most desirable alternatives for protecting human health and the environment. The implementation of an in-place disposal alternative will likely require some type of protective covering to provide long-term isolation of the wastes from the accessible environment. A longterm barrier may still be needed to adequately dispose of the wastes, even if the wastes are exhumed and treated. Currently, no "proven" long-term barrier is available.

The Hanford Site Permanent Isolation Barrier Development Program was organized to develop the technology needed to provide a long-term surface barrier capability for the Hanford Site. This technology could also be adapted to other sites. The program, which is divided into several tasks, is being jointly conducted by Pacific Northwest Laboratory (PNL) ${ }^{(a)}$ and Westinghouse Hanford Company (WHC) and is sponsored by the U.S. Department of Energy's Environmental Restoration Program.

Permanent isolation barriers use engineered layers of natural materials to create an integrated structure with redundant protective features. A key component of the Hanford Permanent Isolation Barrier (HPIB) is the use of a two-layer asphalt system, which provides backup water diversion capabilities if the primary earthen barrier falls short of meeting infiltration goals. The use of the twolayer asphalt system also provides $\operatorname{RCRA}^{\text {(b) }}$ equivalency.

This test plan describes the work planned by PNL, from FY 1994 to FY 1997, to develop asphalt barrier technologies. Work tasks detailed in this test plan include asphalt longevity, asphalt barrier physical properties, asphalt analogs, 1994 RCRA equivalency, and asphalt distortion. The

objectives of these tasks include developing accelerated aging tests and evaluating the performance of samples under accelerated conditions; comparing the results of the tests with asphalt artifact analogs, and modeling the degradation of the selected asphalt composite to make life-cycle predictions. A description of the overall HPIB is also included.

(a) Operated for the U.S. Department of Energy (DOE) by Battelle Memorial Institute under Contract DE-AC06-76RLO 1830.

(b) Resource Conservation and Recovery Act of 1976. 


\subsection{Hanford Permanent Isolation Surface Barrier}

A drawing of the conceptual permanent isolation surface barrier is shown in Figure 2.1. The objective of the current design is to use natural materials to develop a maintenance-free permanent isolation surface barrier that isolates wastes for a minimum of 1000 years (DOE 1993) by limiting water drainage to near-zero amounts; reducing the likelihood of plant, animal, and human intrusion; controlling the exhalation of noxious gases; and minimizing erosion-related problems. The natural construction materials (e.g., fine soil, sand, gravel, riprap, asphalt) have been selected to optimize barrier performance and longevity.

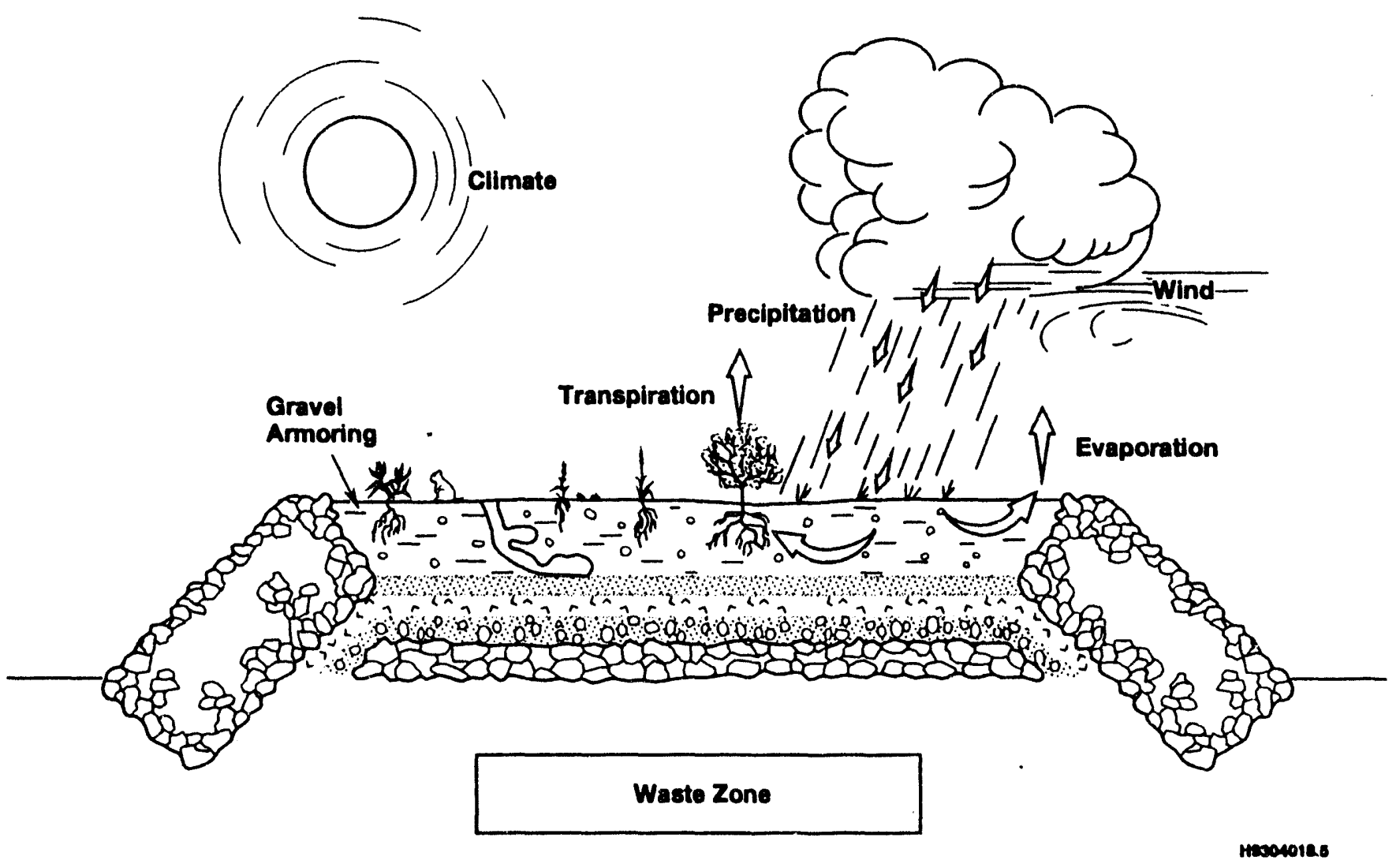

Figure 2.1. Conceptual Design of the Permanent Isolation Surface Barrier

\subsection{Need for Permanent Isolation Surface Barriers}

Permanent isolation surface barriers were identified in the Hanford Waste Management Plan (DOE 1987) and the Final Environmental Impact Statement for the Disposal of Hanford Defense HighLevel, Transuranic, and Tank Wastes (HDW-EIS) (DOE 1988) as integral components in the final disposal schemes for the following wastes: 
- single-shell tank wastes

- transuranic-contaminated soil sites

- pre-1970 buried suspect transuranic-contaminated solid wastes

- grouted low-activity and low-level wastes from double-shell tanks.

In addition to the waste types identified above, other forms of waste may require permanent isolation surface barriers. These other forms of waste include decommissioned facilities, low-level waste sites, and hazardous waste sites. Furthermore, permanent isolation barriers have been identified as an integral component of the large-scale remediation approach to cleaning up the Hanford Site.

While certain barrier designs are currently available (EPA 1982; EPA 1990), the design life is for relatively short periods-such as the 30-year post-closure period specified by RCRA. In light of these short-term designs, the development, testing, and evaluation of permanent isolation barriers is critical considering the long-term Hanford Site mission of environmental restoration and for meeting key milestones, including the Hanford Federal Facility Agreement and Consent Order (Tri-Party Agreement) milestones. A barrier (final cover) is needed to support: Milestone M-08-00, Initiate Full-Scale Tank Farm Closure Demonstration Project, by June 2004; Milestone M-09. 01, Complete Preparation of Supplemental EIS by June 2002; and Milestone M-09-00, Complete Closure of All 149 Single Shell Tanks, by June 2018.

\subsection{Functional Requirements for Permanent Isolation Surface Barriers}

Certain types of waste at the Hanford Site (and elsewhere) may be disposed of using in-place stabilization techniques. Much of the waste that would be disposed of by in-place stabilization is now located in relatively shallow subsurface structures such as solid waste burial grounds, tanks, vaults, and cribs.

The protective barrier design consists of several layers, each with a specific purpose to protect the waste from transport pathways. Figure 2.2 illustrates a cross-sectional view of the HPIB. The fine-soil layer acts as a medium in which moisture is stored until the processes of evaporation and transpiration recycle any excess water back to the atmosphere. The fine-soil layer also provides the medium for establishing plants that are necessary for transpiration to take place. The coarser materials placed directly below the fine-soil layer create a capillary break that inhibits the downward percolation of water through the barrier. The placement of the silt loam directly over the underlying coarser materials also creates an environment that encourages plants and animals to limit their natural biological activities to the upper, fine-soil portion of the barrier, thereby reducing biointrusion into the lower layers. The coarser materials also will help to seter inadvertent human intruders from digging deeper into the barrier profile.

Low-permeability layers, which are placed in the barrier profile below the primary earthen layers, divert from the waste zone any percolating water that gets through the earthen $\operatorname{cover}^{(\mathrm{a})}$ and limit the upward movement of noxious gases from the waste zone (Terrel 1991). The coarse materials located above the low-permeability layers also serve as a drainage medium to channel any percolating water to the edges of the barrier.

(a) Vallerga, B. A. 1992. Characterization Study of Asphalt Concrete Barrier Materials for Radioactive Waste Vaults. Draft: Prepared for Kaiser Engineers Hanford by B. A. Vallerga, Inc. 


\section{Typical Barrier Cross Section}

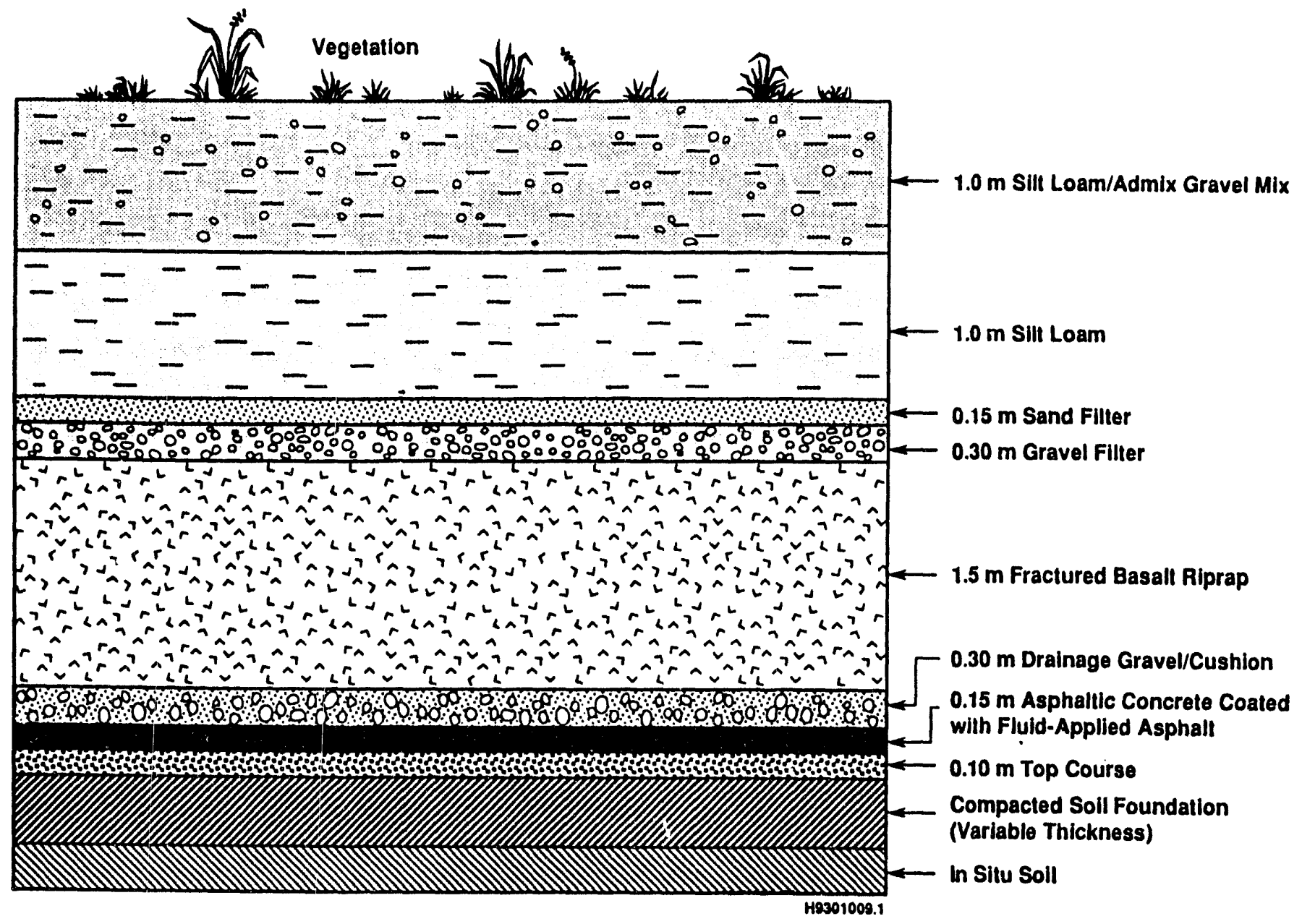

Figure 2.2. Cross-sectional View of HPIB

\subsection{Role of Asphalt in the Permanent Isolation Surface Barrier}

A composite asphalt barrier (fluid-applied polymer-modified/asphalt-aggregate mixture is being considered as an alternative to the RCRA bentonite clay/high density poly(ethylene) (HDPE) barriers for the low-permeability component of the HPIB. It is believed, if not fairly well accepted, that HDPE liners and clay barriers will be incapable of performing over the proposed design life of most surface barriers. Asphalt, on the other hand, appears to be capable of performing to specification over the 1000-year design life criterion. The complex chemistry of asphalt is perhaps its biggest advantage over most other construction materials.

\subsubsection{Historical Background}

Natural asphalt, or bitumen, has been exploited for a documented 5000 years, and may have been used by prehistoric peoples for a considerably longer period. Available worldwide in surface or readily accessible deposits, asphalt is a transitional phase in the evolution of crude oil, in which lighter, volatile fractions have been removed through evaporation, mechanical processes, thermal 
alteration, or high pressure (Hellmuth 1989). The state of the material's evolution, differences in the composition of the parent material, and the process(s) to which it has been subjected all account for the extreme variability found in the physical and chemical characteristics of asphalt. However, asphalts from a majority of sources share common features, which made them attractive to early cultures: a high degree of water repellency, lack of volatility, pronounced adhesiveness, impermeability, and longevity. These same properties have stimulated interest in incorporating asphalt into nuclear waste containment systems.

Wherever natural asphalt outcroppings occur, asphalt artifacts are found in archaeological deposits. The earliest recorded use of asphalt, which dates to 3250 B.C. ( 5200 B.P.), comes from the Mesopotamian and Indus civilizations of the Middle East (Forbes 1955). Asphalt was used as mortar, stucco, sealant, waterproofing agent, and embalming material. It was also an important trade and tribute item throughout the region. Accounts of early asphalt use from this region abound, due primarily to its availability.

Asphalt from Val de Travers in Srvitzerland was used by prehistoric lake dwellers as a preservative for underwater building supports (Nellensteyn 1938). There are numerous accounts of prehistoric asphalt use in North America, ranging from the famous "Seneca Oil" of the Seneca Indians of the northeastern United States (Giddens 1974) to Florida and Texas (Dedera 1976), into the Mexican Gulf states of Tamaulipas and Vera Cruz, where asphalt was used as flooring in temple mounds 3000 years old (Muir 1926), and west into Utah and Wyoming (Dedera 1976).

Some of the best documented prehistoric accounts of asphalt use in North America come from the Santa Barbara Channel region of California, where its use was reported by early Spanish explorers (Fages 1875). Asphalt artifacts dating to 5000 years B.P. have been recovered from archaeological sites throughout the region (Moratto 1984; Gutman 1979, 1983; Heizer 1943; Rogers 1929). Many reported artifacts from the Santa Barbara Channel were found in graves, which makes them most suitable as analogs of a buried moisture barrier (the composite asphalt barrier).

\subsubsection{Composite Asphalt Barrier}

A composite asphalt barrier was selected for use in the HPIB for several reasons. Low air void, high-asphalt-content hot-mix asphalt concretes (HMAC) are noted for low permeability and improved mechanically stable compositions. ${ }^{(a)}$ HMAC exhibits a range of perrneabilities and physical stability characteristics (Terrel 1991; Tuffour and Ishai 1990; Periasamy et al. 1990). The higher the asphalt content, the lower the permeability and the better the physical stability. At asphalt contents above $20 \mathrm{wt} \%$, asphalt/aggregate mixes (concrete) were shown to be extremely effective in controlling radon emanation from uranium mill tailings (Hartley et al. 1981; Gee et al. 1989). Liners with high asphalt content also have been tested successfully and shown to minimize leachate losses from stored liquid wastes (Buelt et al. 1981).

The composite asphalt barrier has the excellent physical properties (tensile strength, elongation, etc.) needed to withstand failures caused by waste form subsidence. Furthermore, HMAC covers have been shown to be effective in preventing root and animal penetration. Studies with vegetation growing above an asphalt layer show that roots are unable to penetrate an $8-\mathrm{cm}$-thick asphalt/

(a) Vallerga, B. A. 1992. Characterization Study of Asphalt Concrete Barrier Materials for Radioactive Waste Vaults. Draft: Prepared for Kaiser Engineers Hanford by B. A. Vallerga, Inc. 
aggregate layer. Similarly, animals (ground squirrels and prairie dogs) confined to digging in shallow soil immediately above an asphalt layer were unable to penetrate the $8-\mathrm{cm}$-thick layer (Cline et al. 198?).

Finally, HMAC is a widely used construction material with well-documented engineering properties and construction techniques. The construction technology is already deployed and readily available for large-scale testing and demonstration for utilization in the HPIB.

Measuring or estimating physical degradation rates of the asphalt components of the HPIB is required to establish a confidence level in long-term barrier performance. Changes in properties such as shear stress, elasticity, and permeability need to be known, and current data bases provide a way to estimate changes in these properties for asphalt layers for the extremely long durations specified.

A number of examples and references can be used to infer the long-term behavior of asphalt. As noted above, asphalt has been used for many years (5000 B.C.) as a barrier to water infiltration because of its impermeable nature (Forbes 1955). However, most of the data available on the performance properties of asphalt barriers are from freshly manufactured materials. A large portion of this information is available in literature associated with the use of asphalt as a matrix for solidification of low-level radioactive wastes (MRM Partnership 1988; Fuhrmann et al. 1989; Fitzgerald et al. 1970). Some of the data associated with solidification of low-level radioactive wastes will be useful, but generally these data do not address the specific needs of subsurface barriers. While there have been numerous studies on asphalt (or bitumen) components as a waste stabilizing agent there have been no comprehensive tests to evaluate asphalt as an integral part of a long-term barrier. The work developed for this test plan was designed to fill some of the technology gaps as needed for the HPIB. 


\subsection{Asphalt Technology Development}

The objective of the Asphalt Technology Development is to provide data to support the lifecycle predictions for the composite asphalt component of the HPIB. This objective will be accomplished by the following activities:

- developing a defensible accelerated aging test, for both components of the composite asphalt barrier, that is representative of the anticipated HPIB service life

- conditioning samples under accelerated aging conditions and evaluating their level of performance

- comparing the results from accelerated aging tests with those from the study of asphalt artifact analogs

- modeling the rate and extent of degradation expected for the asphalt components of the HPIB in order to estimate maximum time of compliance for the asphalt components of the barrier

- monitoring the effectiveness of the asphalt component of the prototype HPIB being constructed in the 200 Area.

The performance criteria to be used to evaluate the HPIB include hydraulic conductivity (to evaluate barrier permeability and establish RCRA equivalency) and static creep compliance (to evaluate response to waste form subsidence).

\subsection{Accelerated Aging Procedure Development}

Much of the work planned for the Asphalt Technology Development depends on the development of a defensible accelerated aging protocol. This protocol must identify conditions that can accelerate the asphalt aging mechanisms sufficiently that a 1000-year exposure to a subsurface environment similar to that expected for the HPIB can be simulated in weeks or months. Ideally, the accelerated aging test conditions would simply accelerate the normal aging mechanisms (e.g., chemical reactions) without causing entirely different reactions to occur. The accelerated aging test procedure will be developed by performing a series of accelerated aging exposure tests over a range of pressures and temperatures for varying periods of time.

\subsubsection{Background}

Much research has been performed on understanding the mechanisms of asphalt aging (Mill 1990; Petersen 1990; Quddus and Khan 1990). Scientists studying asphalt chemistry have extensively investigated the aging phenomenon. The majority of the work has been associated with the asphalt pavement industry, where the time frame of consideration is about 15 to 30 years (the design life of a typical modern pavement). In this research, scientists have employed accelerated aging tests using elevated temperature levels, increased $\mathrm{O}_{2}$ concentrations, and time to simulate aging over the life cycle of pavement (Bell 1990; Petersen 1990). Development of accelerated tests and interpretation of experimental results have been based on the analysis of a large number of samples which were aged in the field (Petersen 1990; Quddus and Khan 1990; Bell 1990). These field-aged samples were 
exposed to moisture, actinic light, temperature extremes, and dynamic and static loads from traffic. Recent results have established a good correlation between laboratory accelerated aging procedures for asphalt cements (pure asphalt) and naturally aged asphalt cements in the field (SHRP 1992).

The environment for surface barriers is much different from those for asphalt pavements. Most importantly, the barriers will not be subjected io temperature extremes (pavement temperatures up to $60^{\circ} \mathrm{C}$ are not uncommon) and exposure to ultraviolet (UV) radiation. UV radiation is one of the most important initiators for oxidation reactions in asphalt, as with most organic materials. Unfortunately, there are no 1000-year-old asphalt barriers to sample and use as a basis of comparison.

Because asphalt is subject to degradation when exposed to light (via UV radiation) and temperature extremes, the asphalt component of a surface barrier (or cap) will be placed well below the surface. The temperature of the installed barrier should remain close to $\sim 15^{\circ} \mathrm{C}$. Oxidation of the asphalt is also expected. However, under conditions of low oxygen-diffusion (expected in a subsurface barrier), the rate of oxidation should be reduced substantially. Rates of decomposition should be markedly lower than those for surface-exposed asphalt pavements. Although asphalt is susceptible to biological decay, rates of biodegradation are estimated to be very low, in the range of a few centimeters in 1000 years (Luey and $\mathrm{Li} \mathrm{1992).}$

The susceptibility of asphalt/aggregate mixtures to various degradation mechanisms also depends on the chemical composition of the asphalt and aggregate (Petersen et al. 1974; Peterson 1990; Halstead 1985; Tuffour and Ishai 1988). The chemical composition of asphalt varies greatly depending on the source of the crude stock and on the refining techniques employed in manufacture. Variations include the following:

- type and concentration of heteroatom species

- ratio of aromatic to aliphatic carbon

- ratio of aromatic to aliphatic hydrogen

- molecular size distribution

- type and content of polar and neutral species.

These variations have a significant impact on the physical properties of an asphalt. The chemical composition will affect the way an asphalt or asphalt mixture responds to aging (accelerated or natural). As asphalts age they stiffen and become more susceptible to cracking. This test plan will specifically address the following aging mechanisms:

- intramolecular oxidation

- uptake of molecular oxygen

- loss of volatiles

- molecular self-assemblage

- poly-condensation reactions.

The chemical composition of aggregates also varies substantially and may influence asphalt aging, physical properties of the mixture, and susceptibility to stripping of the asphalt from the aggregate (Petersen et al. 1974). Aggregates also vary in physical properties such as porosity, gradation, and surface texture. These physical properties have a major influence on the asphalt/ aggregate bonding and, hence, to mechanical stability of the mixture. The HMAC to be used for the HPIB is composed of approximately $92.5 \mathrm{wt} \%$ aggregate. For these reasons, it will be important to include aggregate in designing the experiments for the oxidation studies to characterize the effect of aggregate on test samples. 


\subsubsection{Test Conditions}

Neat asphalt, fluid-applied polymer-modified asphalt, and HMAC components of the HPIB will be exposed to accelerated aging conditions and analyzed chemically and physically. The results of these experiments will be compared against the results from control experiments and unaged and asphalt artifact analog experiments. This analysis is expected to tie the results of the accelerated aging experiments to a time line defined by unaged and asphalt artifact experiments. This will provide the support required to establish the longevity of the materials used for the composite asphalt barrier.

Three asphalts will be used to develop the accelerated aging procedure: U.S. Oil and Refining AR-4000 asphalt; the asphalt specified for use in the prototype barrier; and AAG-1 from the Strategic Highway Research Program - Materials Reference Library (SHRP-MRL). AAG-1 is an AR-4000 graded asphalt. AAG-1 was selected from the SHRP-MRL because it has been characterized in the SHRP program as having an extremely low susceptibility to aging, according to Dr. Jan Branthaver and Dr. David Jones of SHRP.

The accelerated aging procedure will be developed in two phases. Phase 1 will ensure that experimental test configurations and techniques provide comparable results to previous work. Tests that will be conducted during this first phase include the following:

- rheology

- viscosity

- elemental analysis

- penetration

- thin film oven test (TFOT).

The analyses outlined in Phase I are similar to those used to characterize asphalt cements in the SHRP-MRL (SHRP 1992). This point is significant for several reasons as these analyses 1) provide an excellent control for experimental results when using asphalt AAG-1 (from the SHRP-MRL), 2) allow better comparison with experimental results from the U.S. Oil and Refining AR- 4000 with AAG-1, and 3) provide a strong link to the other SHRP-MRL asphalt that will be used in the Physical Properties Work Task of this study.

The second phase of testing and analysis is designed to provide the performance data necessary to tie laboratory data to an asphalt longevity time line. The following chemical and physical procedures will be used to characterize the asphalt barrier materials before and after accelerated aging:

- quantitative infrared spectroscopy (IR)

- high pressure liquid chromatography-size exclusion chromatography (HPLC-SEC)

- Marshall stability

- indirect tensile strength

- accelerated permeability

- multi-axial or static creep analysis.

Tests conducted in FY 1994 will primarily be directed at developing a defensible accelerated aging test and obtaining baseline data on performance of the barrier components. The information obtained in this work task will provide data on chemical and physical properties for the components of the HPIB as a function of oxygen (air) concentration, temperature, and time of conditioning. It is expected that the chemical and physical properties of the aged materials will be substantially different 
from those of newly produced materials. Data obtained in these tests will provide the basis for determining the best accelerated aging conditions for simulating extremely long-term exposure conditions. Data from the long-term exposures will be used to estimate barrier properties after extremely long periods.

The experimental conditions for these tests (see Table 3.1) were selected based on asphalt aging work performed in the SHRP and from best estimates of the depositional environment of the HPIB. The range of temperatures $\left(100^{\circ} \mathrm{C}-25^{\circ} \mathrm{C}\right)$ and $\left[\mathrm{O}_{2}\right](300 \mathrm{psi}$ air to inert atmosphere) and time of conditioning were selected based on experimental conditions developed in the SHRP program.

Experiments conducted in the SHRP program have shown that asphalt samples may be conditioned to simulate 15 to 20 years of aging for an asphalt pavement. This correlation will not be used directly in the PNL studies because of the differences between the depositional environments of the barrier and pavements. However, it will be used as a control for evaluating reproducibility of the experimental method. Although the conditions by which asphalt pavements and the HPIB asphalt components age are very different, the data derived from these experiments wili provide a much needed point of reference. Logical perturbations of experimental conditions outlined in SHRP and those more simulative of the depositional environment of asphalt components in the HPIB will be used.

Table 3.1. Experimental Conditions for FY 1994 Accelerated Aging Study

\begin{tabular}{|c|c|}
\hline Temperature & Atmosphere \\
\hline $25^{\circ} \mathrm{C}^{(\mathrm{a})}$ & $\begin{array}{l}\text { inert } \\
\text { ambient } \\
100 \text { psi air(b) } \\
300 \text { psi air }\end{array}$ \\
\hline $50^{\circ} \mathrm{C}$ & $\begin{array}{l}\text { inert } \\
\text { ambient } \\
100 \text { psi air } \\
300 \text { psi air }\end{array}$ \\
\hline $75^{\circ} \mathrm{C}$ & $\begin{array}{l}\text { inert } \\
\text { ambient } \\
100 \text { psi air } \\
300 \text { psi air }\end{array}$ \\
\hline $100^{\circ} \mathrm{C}$ & $\begin{array}{l}\text { inert } \\
\text { ambient } \\
100 \text { psi air } \\
300 \text { psi air }\end{array}$ \\
\hline
\end{tabular}

(a) Temperatures will be maintained within $\sim 3^{\circ} \mathrm{C}$ of experimental plan.

(b) Pressures will be maintained within $2 \%$ of experimental plan. 
Neat asphalt and asphalt/aggregate test specimens, placed in steel pressure vessels, will be exposed to the conditions outlined in Table 3.1 for varying periods of time. During the initial stages of the high-temperature/high $\left[\mathrm{O}_{2}\right]$ experiments, the interval for sampling will be relatively short, 12 to 48 hours. The viscosity will be determined and qualitative IR will be performed on these specimens to determine if sufficient degradation has occurred and to decide which experiments will be extended for further analyses. The criteria for continuing long-term experiments will be based on IR, HPLCSEC, accelerated permeability and indirect tensile strength measurements. If these observations indicate an obvious failure in the material properties of the asphalt (rendering it unsuitable for this engineering application), then the experiment would be concluded. Also, experiments will be stopped if mechanical test data show a material failure. The actual number of samples to be analyzed is an unknown, because the length of time required to condition the samples is not known.

\subsubsection{Analytical Techniques}

It is critical that the data generated in this study have a firm connection to historical data. Therefore, a series of experiments will be performed which will provide a clear scientific description of the asphaltic materials to be used in this research. The asphalt cements will be characterized by techniques outline in the SHRP-MRL.

IR spectroscopy will be used to monitor changes in chemical functional groups present in asphalt barrier components as a result of accelerated aging conditioning (Petersen 1986). Quantitative functional group analysis will be performed to specifically characterize the following products of oxidative aging: phenolic, pyrolic, sulfoxide, carbonyl, ketone, carboxylic acid, and anhydride functionalities. The rate by which an asphalt oxidizes will have a significant effect on physical properties that will influence permeability and physical properties. Samples for analysis by IR and HPLC will be recovered from the asphalt mixtures and neat asphalt coupons by dissolving a portion of the sample in spectral-grade tetrahydrofuran (THF).

HPLC-SEC will be used to measure changes in the molecular size distribution caused by condensation reactions and loss of volatiles. In this technique, samples are dissolved in a suitable solvent and passed through a column of macroreticular styrene-divinylbenzene beads. These beads have very small openings ( $5 \AA$ and greater). The smaller molecules in the samples will be retained in the openings (retention time is a function of molecular size), while larger molecules will be carried along in the eluent. Through this mechanism a separation based on molecular size is achieved. HPLC-SEC data will be used to monitor the increase in the molecular size distribution as the result of oxidative aging (Jennings 1985). HPLC-SEC will also be used to evaluate self-assemblage in the asphalt (Brule et al. 1986; Glover et al. 1987). HPLC-SEC data, with weight change data, will be used to determine the loss of volatiles.

The configuration of the asphalt mixture specimens for the accelerated permeability studies will be the standard 2-in.-thick and 4-in.-diameter Marshall compacted specimen configuration. The permeameters are of a similar configuration to those used for obtaining accelerated permeability measurements for compacted soils (ASTM D-2434 1993). The permeameters will provide the most important information of this study: does the composite asphalt barrier out perform the standard RCRA HDPE-bentonite clay impermeable barrier $\left(10^{-7} \mathrm{~cm} / \mathrm{s}\right)$ ?

Mechanical tests will be performed on HMAC samples. The configuration of the samples will be based on the sample configuration required for the mechanical test static creep or multi-axial loading (Steffen 1984). The asphalt used in the HPIB will physically harden through loss of volatiles, 
oxidation, condensation reactions, etc. This phenomenon could be beneficial (by lowering permeability). However, there will be a point where the asphalt will become so hard or brittle that could be susceptible to cracking caused by waste form subsidence. The mechanical data will help establish the required mechanical properties of the asphalt barrier components to determine how much waste form subsidence this barrier configuration can stand before failure. The mechanical test results will provide physical data that can be used with chemical data to predict the performance of the barrier.

\subsubsection{Experimental Methods}

The experimental methods that will be used in this study are described below.

\subsubsection{Sample Preparation}

Asphalt cements will be handled according to the Technical Procedure: Asphalt Handling Protocol (Romine 1992). Asphalt mixture samples will be prepared according to ASTM procedures (ASTM D-1559 1992). Aggregate to be used will be obtained from ACME Concrete, Richland, Washington, and will have a size gradation as described in Table 3.2.

Table 3.2. Aggregate Gradation for Laboratory Mixture Samples ${ }^{(a)}$

\section{Nominal Square Opening Agqregate Size}

$5 / 8$ in.

$1 / 2$ in

$3 / 8$ in.

No. 4

No. 18

No. 30

No. 45

No. 200

\section{Percent Passing}

100

90 to 100

85 to 95

65 to 75

36 to 42

27 to 33

17 to 21

4.5 to 6.5

(a) Larger aggregate sizes will not be used to minimize the influence of aggregate size if required by sample configuration constraints.

The asphalt will be heated to $135 \pm 10^{\circ} \mathrm{C}$ and stirred to a smooth consistency before being added to the aggregate. The amount of asphalt added to the dry aggregate will be $7.5 \mathrm{wt} \% \pm$ $0.1 \mathrm{wt} \%$ of the total mix. The asphalt and aggregate will be mixed in a Hobart Mixer as described by ASTM D-1559. The compaction mold and steel base will be placed in an oven at $135 \pm 5^{\circ} \mathrm{C}$ and allowed to equilibrate. Equilibration should take less than 2 hours.

Sufficient loose mixture will be placed in the compaction mold to produce a 2-in.-thick compacted sample. The expected compacted density is approximately $2.38 \mathrm{~g} / \mathrm{cm}^{3}$. The weight of the material required to make the 2 -in.-thick sample will be recorded. The remaining samples will weigh 
within $1.0 \mathrm{~g}$ of the original sample. The samples will be compacted according to the Marshall compaction procedure (ASTM D-1559 1992). The number of blows required to achieve proper air void content will be determined from previously performed mixture designs.

Samples will be exposed to experimental conditions in a sealed steel pressure vessel made from Schedule 40 carbon steel pipe with a 300 -lb flange at one end and a welded solid cap at the other. Each pressure cell will hold three replicate samples of HMAC specimens and asphalt-cement samples. One pressure cell will be used for each exposure condition identified in Table 3.1. Test cells will be placed in water baths to control exposure temperatures for low-temperature experiments. Hightemperature experiments will be performed in ovens. At each time interval, the appropriate cells will be removed and samples tested.

It is hoped that time/temperature superposition can be used to obtain certain physical properties of HMAC samples, such as indirect tensile strength. It is anticipated that many of the mechanical properties of aged samples may be obtained without extensive accelerated aging of compacted HMAC samples. If the use of time/temperature superposition is possible, then problems associated with exposing compacted HMAC specimens to high pressures can be avoided. Microfracturing and other physical damage occurs to HMAC and neat asphalt samples aged at high pressures if the pressure is released too rapidly.

If time/temperature superposition can not be utilized in this work, then it will be necessary to develop approaches to minimize damage to HMAC samples aged at elevated pressures. Thus, the pressure will be released slowly to prevent specimens from being damaged. At the end of the conditioning period, nitrogen will be used to replace the oxygen in the accelerated aging vessels in order to prevent additional oxidation while the pressure is being slowly reduced. The time required to reduce the pressure without damaging the specimens is related to the initial pressure the samples were exposed to. The pressure on samples conditioned at 300 psi will be released on a 1:1 basis ( 3 weeks at 300 psi:3 weeks to achieve atmospheric pressure). The pressure on samples conditioned at 100 psi will be released on a 2:1 basis (2 weeks at 100 psi: 1 week to achieve atmospheric pressure). The rate of pressure drop will be varied to determine if a faster decompression period may be used.

Neat asphalt samples and the polymer-modified asphalt component of the HPIB will be included in the accelerated aging test chambers. One $\pm 0.1 \mathrm{gram}$ of neat asphalt will be poured into a Teflon form. Samples of the polymer-modified asphalt component of the composite barrier will be made in a Teflon form. These samples will be placed in the accelerated aging test apparatus and conditioned alongside the HMAC samples.

Samples for analysis by IR and HPLC will be recovered from HMAC and asphalt cement samples by dissolving a portion of sample in spectral-grade THF. Samples for chemical analysis will be obtained from the HMAC and polymer-modified asphalt samples after the mechanical tests have been performed. The IR and HPLC analysis will be initiated within 30 minutes of dissolution to avoid chemical oxidation of the samples by the THF.

\subsubsection{Analytical Methods}

The following analytical methods will be used during the project.

3.1.4.2.1 Infrared Spectroscopy. The IR quantitative functional group analysis protocol to be used is described previously by Petersen (1986). 
3.1.4.2.2 High Pressure Liquid Chromatography. The HPLC-SEC method to be used is described in the Proceedings of the Association of Asphalt Paving Technologist

(Jennings 1985). Multiple eluents (THF and toluene) and modified separation conditions will be used to study molecular size distribution and molecular self-assemblage behavior (Brule et al. 1986; Glover et al. 1987). The column configuration for the PNL analyses is a single $1000 \AA$ (500 mm $\times 15 \mathrm{~mm})$ column.

3.1.4.2.3 Weight Change. The procedure to be used to determine the change in weight is as follows:

- After allowing compacted asphalt mixture sample to cool to $25 \pm 1^{\circ} \mathrm{C}$, weigh to nearest $0.001 \mathrm{~g}$.

- After conditioning in accelerated aging apparatus, reweigh compacted mix sample to the nearest $0.001 \mathrm{~g}$.

- Determine thu percent change in weight.

- Perform the same procedure for the neat asphalt samples.

3.1.4.2.4 Mechanical Analysis. Indirect tensile strength measurements will be used as a screening test for mechanical analysis. Multi-axial loading and static creep analysis will be performed when more quantitative data are required (Steffen 1984). Any procedures used will be evaluated according to QA Level II protocols.

3.1.4.2.5 Accelerated Permeability Analysis. A procedure to measure the hydraulic conductivity of the HMAC component of the HPIB is being developed in FY 1994. The test vessel is similar to those used in determining the hydraulic conductivity of compacted soils (ASTM D-2434 1993). Permeability measurements are performed on standard Marshall compacted HMAC. samples. The permeameter is made with a 4.5 -in.-i.d. Plexiglas tube with Plexiglas end caps. The bottom onehalf inch of the annulus is filled with cured Silicone-RTV. The remainder of the annulus is filled with asphalt cement. The cell is gasketed, capped, and pressurized with a constant 10 to 20 psi head of water. The conductivity is measured when flow of the water through the sample comes to an equilibrium. A new method (Fallow et al. 1993) to obtain permeability data using initial transient water infiltration data are also currently being evaluated for use in the laboratory and as a field monitoring technique. The advantage of this technique is that permeability estimates can be obtained in a matter of hours instead of days or weeks. Its applicability to asphalt materials is yet to be determined.

\subsubsection{Asphalt Aging Conditions}

The matrix of aging conditions (asphalt and aggregate source, temperature, oxygen pressure, trace gases, and time) will be determined after the accelerated aging protocol has been established (FY 1995). First, information will be gathered on likely candidate sites for the HPIB so site-specific information can be evaluated. Information such as the form of the waste, potential noxious material generation and rates, potential modifications to the base HPIB design (e.g., overall thickness of barrier and/or changes in layering sequences) must be considered when developing a testing plan. These factors will be used to develop a test matrix based on factorial statistical designs to minimize the number of tests that must be performed. During FY 1994 baseline data on unaged HMAC can be obtained for a limited number of asphalt and aggregate sources. These data will provide a reference for observed changes in physical properties in aged asphalt. 


\subsubsection{Physical Property Tests}

A number of physical property tests will be conducted on the aged and unaged test specimens. Most of these tests are geared towards the HMAC, although some are performed on the asphalt cements. The objective of performing these tests is to provide sufficient data to estimate the longterm performance of the asphalt component of the HPIB under a range of disruptive events. This means that the fundamental data of most importance are the stress-strain relationships, static creep information, and the effects of strain on water permeability. In support of these relationships, other basic information such as air voids, bulk density, asphalt content, Marshall stability, and asphalt cement viscosity will be obtained. All tests will be performed in accordance with established ASTM procedures.

\subsection{Asphalt Analogs}

The strategy for assessing the long-term performance of asphalt as a buried moisture barrier involves artificially aging natural asphalt and testing its mechanical and hydraulic properties. The Asphalt Analogs Work Task will acquire a dated series of archaeological asphalt, ranging in age from 500 to 3000 years, along with naturally occurring asphalt (control asphalt) from the same vicinity. The control asphalt will be exposed to accelerated aging conditioning. The asphalt artifacts and the aged and unaged control asphalt will be compared chemically to develop a better understanding of chemical reactions of asphalt during extremely long-term aging in a reduced oxygen environment and in the absence of UV radiation. The result of this study will be an aging curve that can be used to "calibrate" the accelerated aging procedure developed in the Asphalt Longevity Work Task.

\subsubsection{Background}

Certain asphalt artifacts were intentionally buried soon after they were created. These artifacts are analogous the proposed composite asphalt barrier in being heated and formed within a short time before being sealed from light and most oxygen. The archaeological specimens remained buried until their discovery, often many centuries later.

Archaeological asphalts are expected to provide valuable data on asphalt aging, not available from any other source, linking accelerated aging results to a time line for buried asphalt. This information can then be used to evaluate the performance of the asphalt components of the HPIB. The analysis of the seep materials and the asphalt artifacts provides a unique opportunity to study the aging response of an asphaltic material in a depositional environment analogous to that of the Hanford barriers. The range in the ages of the artifacts corresponds to the anticipated design life of the Hanford barriers.

\subsubsection{Approach}

Despite extensive research into the aging of surface-exposed asphalt, very little data are available on the performance of this material in buried settings. This study will follow a six-step procedure to obtain data on the aging of buried asphalt from artifacts of asphalt manufactured by the ancients.

1. Museum collections of asphalt artifacts will be located, and samples of artifacts and associated organic materials will be obtained. Two source areas, the Santa Barbara Channel and another yet to be named, will be studied. 
2. Samples will be obtained from the natural asphalt seeps (control asphalt) believed to have been the source of material for the artifacts.

3. Organic material found associated with the artifacts will be radiocarbon dated to establish the time of asphalt artifact manufacture and burial.

4. Elemental analysis will be performed both on artifacts and on natural asphalt to verify that the artifacts contain asphalt from presumed local sources.

5. Control asphalt will be exposed to accelerated aging conditions.

6. Artifacts and control asphalt samples will be chemically analyzed, as described in the Asphalt Longevity Work Task, by the IR and HPLC-SEC and compared to discern changes attributable to long-term burial.

Results will be used to generate a time line for use in "calibrating" the accelerated aging procedure and to help determine the performance of aged asphalts.

\subsubsection{Selecting Archaeological Samples}

The following criteria were used to select archaeological samples from the Santa Barbara region. Sourcing of natural asphalt using nickel/vanadium $(\mathrm{Ni} / \mathrm{V})$ ratios from the Santa Barbara Channel region has been extensively applied (Gutman 1979; Gutman 1983). There are also very detailed ethnographic accounts on asphalt processing methods (Hudson et al. 1978). Additionally, sample artifacts will be limited to those recovered from burial assemblages. In this manner, primary internment of the artifact is established, and the linkage with asphalt to be used for waste containment is strengthened because of the similarity in subsurface environments.

3.2.2.1.1 Santa Barbara Asphalt. The Chumash culture developed over a period of 7000 years along the east/west trending coastline which characterizes the Santa Barbara region (King 1981). The Chumash maintained vast trade networks and used a sophisticated monetary system driven by market forces (Moratto 1984; King 1981; Chartkoff and Chartkoff 1984; Willey 1966; Dibblee 1987). Asphalt played a significant role in the manufacture of numerous art, craft, and utilitarian items. It was used to waterproof and preserve their large, oceangoing canoes; affix ornaments to jewelry, apparel, and specialized items; and to attach arrow points to shafts, knives to handles, baskets to mortars, and fish hooks to lines. Deposits of hardened asphalt were preferred over the softer float material which washed up onto the beaches and accumulated on the rocks (Hudson et al. 1978). Sometimes the asphalt, after being crushed and heated, was used without additives, although it was also mixed with pine pitch and ochre (Hudson et al. 1978).

The climate of the Santa Barbara region for the last 3000 to 4000 years can be described as Mediterranean, with wet, mild winters and dry, warm summers. Interior vegetation is typically scrub chaparral broken by oak groves and open grasslands studded with savannah-form live oaks.

The Santa Barbara Channel is a structural depression capped by sedimentary rocks of Miocene, Oligocene, and Eocene ages (Dibblee et al. 1984). The rugged Santa Ynez Mountains rise to the north, past the narrow, 2 to 5 mile $(3.2$ to $4.8 \mathrm{~km})$ wide coastal plain. These coastal mountains are the result of a tectonic accretionary wedge and consist of a mix of metamorphic and sedimentary rocks (Dibblee et al. 1984). Numerous faults, trending northwest/southeast, dissect the region. The 
reservoir rock for extensive oil, gas, and tar deposits is the Miocene Age Monterey formation, which is capped by quaternary and Pliocene sediments (Figure 3.1). Fractures within the cap rock account for the numerous seeps found throughout the region.

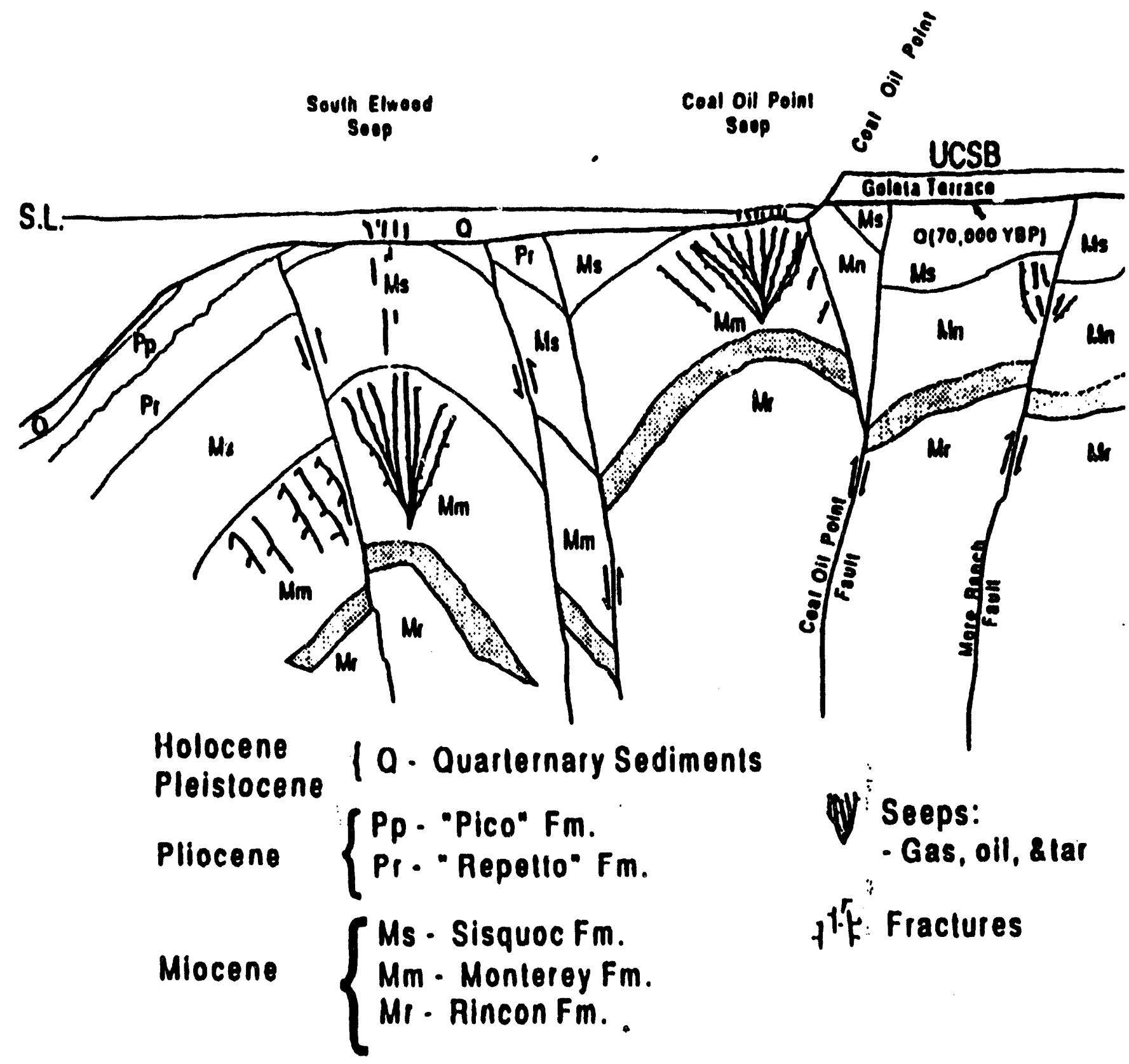

Figure 3.1. Geologic Structure of Petroleum-Bearing Deposits Within the Santa Barbara Channel Region 
3.2.2.1.2 Selection of Additional Santa Barbara Archaeological Samples. Archaeological samples from the Santa Barbara Channel will be obtained from collections at the Santa Barbara County Museum of Natural History; the University of California, Santa Barbara; and the University of California, Los Angeles. Sites from which samples will be chosen will be prehistoric cemeteries of the Chumash Indians, which are close to known asphalt seeps and have been excavated by the aforementioned institutions cver the past 75 years (Figure 3.2). Since discovery, the artifacts have been housed in museum drawers and collection bags where they are not exposed to temperature

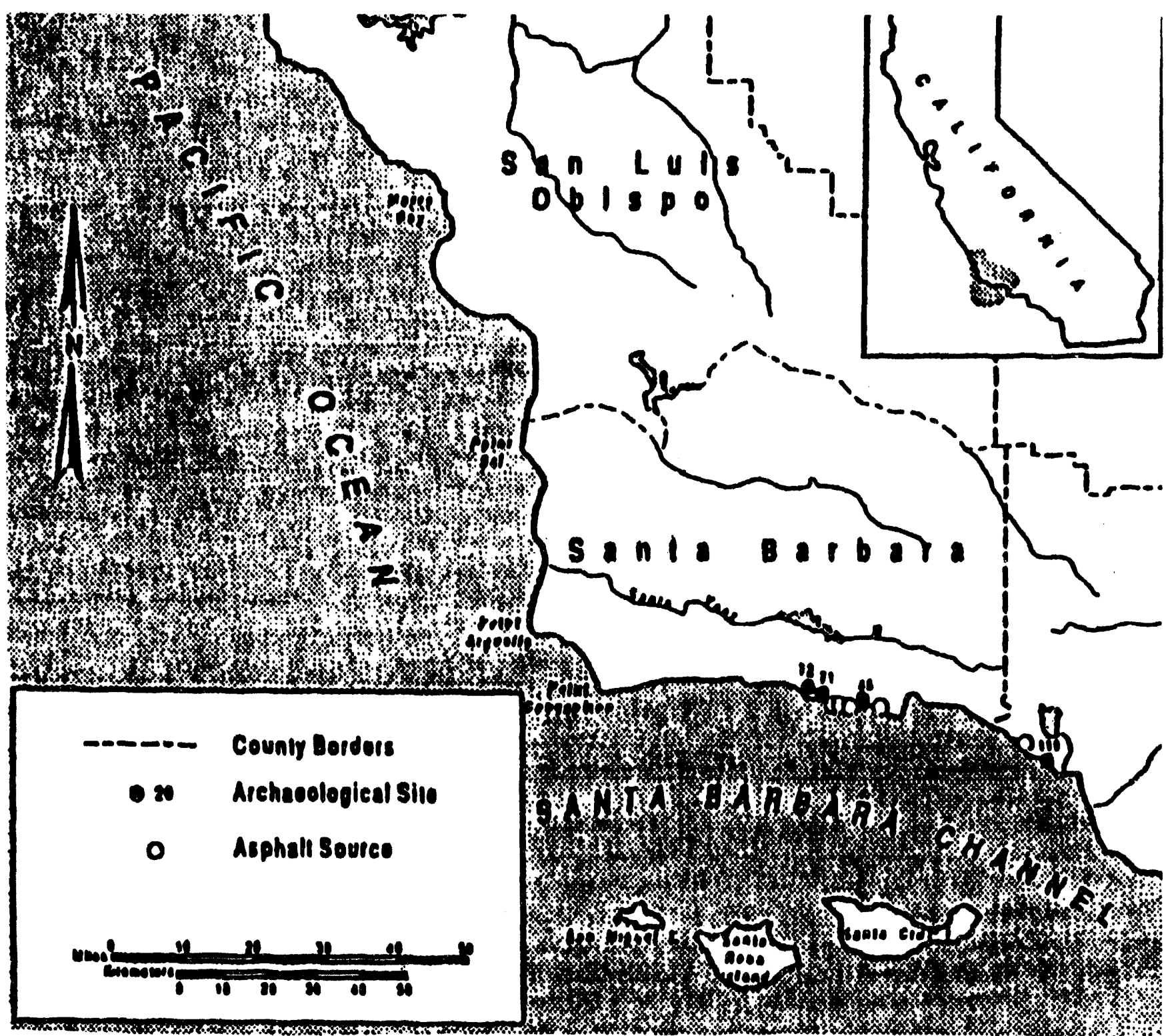

Figure 3.2. Santa Barbara Channel Area Showing Distribution of Asphalt-Containing Archaeological Sites and Asphalt Deposits 
extremes or light. An attempt will be made to obtain specimens of a wide range of presumed age and that are associated with other organic material that can be used for radiocarbon dating. Ideally, 20 to 25 specimens will be obtained, covering a 5000 -year period.

\subsubsection{Selection of Natural (Control) Asphalt Samples}

Numerous major natural seeps of asphaltum occur in the Santa Barbara vicinity. At least $1 \mathrm{~kg}$ of asphalt, enough for source analysis and use in artificial aging experinients, will be obtained from each of several source locations nearest the sampled archaeological sites. Where seep asphalt occurs in differing degrees of hardness, an effort will be made to obtain examples of a range of conditions.

\subsubsection{Determining the Age of Asphalt Artifacts}

Radiocarbon dating will be used to determine the age of the artifact. Wherever possible, specimens of shell, bone, or wood charcoal reported to have been found in the same graves as selected artifacts will be obtained from the museums and radiocarbon dated. Ideally, materials to which asphalt is found adhering will be selected. It will be assumed that the radiocarbon age of the sample is representative of the length of time that the artifacts have been buried in the grave sites. If objects from the same grave cannot be obtained, specimens found nearby in the same geological layer will be used. When asphalt is found adhering to an object to be dated, it will be mechanically removed, if possible, or removed by solvents. The asphalt will be recovered from the solvent under vacuum conditions for later chemical analysis.

\subsubsection{Sourcing the Asphalt Artifacts}

To verify that the asphalt artifacts were manufactured from natural asphalt collected in the field elemental analysis will be performed to determine the $\mathrm{Ni} / \mathrm{V}$ ratio. The $\mathrm{Ni} / \mathrm{V}$ ratio is highly source specific. Results of this procedure will also corroborate previous work on the asphalt to be used in this study (Gutman 1983). This should ensure that the artifacts and natural asphalt will have had the same chemical and physical origin.

Nickel and vanadium concentrations will be determined by atomic absorption (AA) measurements using the procedures described by Fish (1984). The sarples will be digested in hydrochloric and nitric acid and the metals extracted into an aqueous solution for easy analysis.

\subsubsection{Chemical Analysis of Archaeological Asphalt to Determine Aging Effects}

Asphalt artifacts and samples obtained from the asphalt seeps will be analyzed to provide data for estimating the rate and degree of chemical changes in the asphalt artifacts. Neat samples and neat material mixed with pitch, following the recipes described in the anthropological literature, will be analyzed as controls. Deviation from these controls in material of the same seep origin will be interpreted as change attributable to long-term internment conditions. Two chemical procedures will be performed, as described in the Asphalt Longevity Work Task on all samples: functional group analysis by IR (Petersen 1986) and HPLC-SEC (Jennings 1985; Brule et al. 1986; Glover et al. 1987).

\subsubsection{Physical Testing of Aged Control Asphalt}

Control asphalt retrieved from active natural asphalt seeps will be exposed to accelerated aging conditions. The conditions of the accelerated aging experiments will be developed in the Asphalt Longevity Work Task. It is anticipated that enough natural asphalt can be collected that a few specimens for permeability measurements can be generated. 


\subsubsection{Obtaining Additional Analog Samples}

A second set of archaeological samples will be obtained from another asphalt source area and analyzed as described above. The probable source area will be the Middle East, an area from which extensive museum collections already exist and asphalt sourcing and archaeological chronologies are well developed.

\subsection{Application Techniques and RA/QC Issues}

It is anticipated that standard asphalt application equipment will be used to install the asphalt layers in the HPIB. The purpose of this task is to evaluate the use of standard asphalt paving equipment in light of the 1) differences in composition and 2) the stringent performance criteria required to ensure barrier performance over a long time. Also, as part of this subtask, the issue of RCRA equivalency will be addressed. Information will be obtained from the following ways:

- review of current literature

- discussions with asphalt paving equipment manufacturers and experienced asphalt paving contractors

- experience with installation of the test pad and prototype barrier for the 200-BP-1 trench.

The results of the literature search, discussions, and test pad installation will be used to develop guidelines for full-scale HPIB asphalt installation and quality assurance/quality control (QA/QC) techniques.

\subsubsection{Lterature Review}

A literature review will be conducted on asphalt application techniques, including multi-lift HMAC paving and installation of polymer-modified asphalt materials. Emphasis will be placed on recent advancements in techniques for installation of water-impermeable barriers. A review of QA/QC procedures will also be conducted.

\subsubsection{Discussions with Asphalt Application and Paving Contractors}

A number of asphalt application equipment manufacturers and paving contractors will be contacted to gain insight to installation techniques. Emphasis will be placed on those manufacturers and contractors who have extensive experience in installation of water-impermeable systems. We will evaluate suggestions by the manufacturers and contractors on potential modifications to equipment that will improve the rate and quality of asphalt barrier installation.

\subsubsection{Prototype and Test Pad Construction}

One of the major goals for the HPIB program in FY 1994 is the installation of a prototype barrier over the B-57 Crib at the 200-BP-1 Operable Unit. As part of this installation, an asphalt test pad $(\sim 8 \mathrm{~m} \times 20 \mathrm{~m})$ will be constructed nearby to demonstrate that the asphalt layer can meet the desired $<1.6 \times 10^{-9} \mathrm{~cm} / \mathrm{s}$ infiltration rate. This pad will provide an opportunity to 1) evaluate 
construction techniques, 2) perform destructive and nondestructive testing of barrier properties to provide feedback to the QA/QC program, and 3) allow in-place cores to be obtained for further laboratory testing.

Valuable application information will also be obtained during the installation of the asphalt test pad while the prototype barrier is being constructed. This prototype is large enough to warrent fullscale construction techniques that will directly apply to barrier installations. In addition, a wealth of QA/QC data will be obtained during construction that will provide much needed data on the variability of the asphalt barrier properties. Confirmation of short-term ( 3 to 5 years) asphalt permeability performance will be documented by monitoring large pan lysimeters under the asphalt barrier that will ensure any leaks through the asphalt will be detected. Details of the monitoring planned for the prototype barrier may be found in Gee et al. (1993).

The results of the literature search, manufacturer and contractor discussions, and prototype construction experience will be summarized in a topical report on installation and QA/QC guidelines. This report will be issued by the end of FY 1995. 


\subsection{References}

ASTM D-1559. 1992. "Standard Test Method for Resistance to Plastic Flow of Bituminous Mixtures Using the Marshall Apparatus." Annual Book of ASTM Standards, Vol 4.03. American Society for Testing and Materials, Philadelphia, Pennsylvania.

ASTM D-2434. 1993. "Standard Test Method for Permeability of Granular Soils (Constant Head)." Annual Book of ASTM Standards, Vol. 4.01. American Society for Testing and Materials, Philadelphia, Pennsylvania.

Bell, C. A. 1990. "Relationship Between Laboratory Aging Tests and Field Performance of Asphalt-concrete Mixtures." In Serviceability and Durability of Construction Materials - Proceedings of the First Materials Engineering Congress Part, pp. 745-754. Denver, Colorado.

Brule, B., G. Raymond, and C. Such. 1986. "Relationship Between Composition, Structure and Properties of Road Asphalt: State of Research at the French Public Works Laboratory." Transportation Research Record 1096. Transportation Research Board, Washington, D.C.

Buelt, J. L., V. Q. Hale, S. M. Barnes, and D. J. Silviera. 1981. An Evaluation of Liners for a Uranium-mill Tailings Disposal Site-A Status Report. PNL-3679, Pacific Northwest Laboratory, Richland, Washington.

Chartkoff, J. L., and K. K. Chartkoff. 1984. The Archaeology of California. Stanford University Press, Stanford, California.

Cline, J. F., F. G. Burton, D. A. Cataldo, W. E. Skiens, and K. A. Gano. 1982. Long-term Biobarrier to Plant and Animal Intrusions of Uranium Tailings. PNL-4340, Pacific Northwest Laboratory, Richland, Washington.

Dedera, D. 1976. "Petroleum and the American Indians." Exxon, USA 15(3):17-21.

Dibblee, T. W., Jr. 1987. Geologic Map of the Goleta Quadrangle. Division of Mines and Geology, Sacramento, California. United States Geological Survey, Denver, Colorado.

Dibblee, T. W., Jr., R. L. Johnson, J. W. Earley, and R. F. Meyer. 1984. "Field Trip Guidebook: Geology and Hydrocarbon Deposits of the Santa Maria, Cuyama, Taft-McKittrick, and Edna Oil Districts, Coast Ranges, California, 1971." In Exploration for Heavy Crude Oil and Natural Bitumen, ed. R.F. Meyer. AAPG Studies in Geology \#25, Tulsa, Oklahoma.

Fages, P. 1875. A Historical, Political, and Natural Description of California.

Translated by H. I. Priestly. Reprinted in 1972 by Ballena Press, Ramona, California. 
Fallow, D. J., D. E. Elrick, W. D. Reynolds, N. Baumgartner, and G. W. Parkin. 1993. "Field Measurement of Hydraulic Conductivity in Slowly Permeable Materials Using Early-time Infiltration Measurements in Unsaturated Media." Hydraulic Conductivity and Waste Contaminant Transport in Soils, ATSM STP 1142, eds. D. E. Daniels and S. J. Trautwein. American Society for Testing and Materials, Philadelphia, Pennsylvania.

Fish, R. H. 1984. "Comparison and Characterization of Vanadyl and Nickel Compounds in Heavy Crude Petroleums and Asphaltenes by Atomic Absorption Spectrometry." Analytical Chemistry 56:2452-2460.

Fitzgerald, C. L., H. W. Godbee, R. E. Blanco, and W. Davis. 1970. "The Feasibility of Incorporating Radioactive Wastes in Asphalt or Polyethylene." Nuclear Applications and Technology, Vol 9.

Forbes, R. J. 1955. Studies in Ancient Technology, Vol. I. E. J. Brill, Leiden, Netherlands.

Fuhrmann, M., R. F. Pietrzak, J. Heiser, E. M. Franz, and P. Colombo. 1989. Development of an Accelerated Leach Test. BNL-41893, Brookhaven National Laboratory, Upton, New York.

Gee, G. W., M. D. Campbell, H. D. Freeman, and J. F. Cline. 1989. Assessment of Cover Systems at the Grand Junction, Colorado Uranium Mill Tailings Pile: 1987

Field Measurements. PNL-6762, Pacific Northwest Laboratory, Richland, Washington.

Gee, G. W., L. L. Caldwell, H. D. Freeman, M. W. Ligotke, S. O. Link, R. A. Romine, and W. H. Walters, Jr. 1993. Testing and Monitoring Plan for the Permanent Isolation

Surface Barrier Prototype. PNL-8391, Pacific Northwest Laboratory, Richland, Washington.

Giddens, P. H. 1974. The Early Petroleum Industry. Porcupine Press, Philadelphia, Pennsylvania.

Glover, C. J., J. A. Bullin, J. W. Button, R. R. Davison, G. R. Donaldson, M. W. Hlavinka, and C. V. Phillip. 1987. Characterization of Asphalt Using Gel Permeation

Chromatography and Other Methods. Report No. FHWA/TX-87/53+419-1F, Texas

Transportation Institute, Texas A \& M University, College Station, Texas.

Gutman, T. E. 1979. "The Use of Asphaltum Sourcing in Archaeology." Journal of New World Archaeology 3:32-43.

Gutman, T. E. 1983. "Additional Notes on Asphaltum Sourcing." Journal of New World Archaeology 5(3):20-26.

Halstead, W. J. 1985. Relation of Asphalt Chemistry to Physical Properties and Specifications. VHTRC 85-RP2, Virginia Highway and Transportation Research Council, Charlottesville, Virginia. 
Hartley, J. N., P. L. Kochmstedt, D. J. Esterl, H. D. Freeman, J. L. Buelt, D. A. Nelson, and M. R. Elmore. 1981. Asphalt Emulsion Sealing of Uranium Mill Tailings, 1980

Annual Report. PNL-3752, Pacific Northwest Laboratory, Richland, Washington.

Heizer, R. F. 1943. "Aboriginal Ujse of Bitumen by the California Indians." California Bureau of Mines Bulletin 118:74, Sacramento, California.

Hellmuth, K-H. 1989. Natural Analogues of Bitumen and Bituminized Radioactive Wastes. Stuk-B-Valo 58, Säteilyturvakeskus, Strålsäkerhetscentralen Finnish Centre for Radiation and Nuclear Safety, Finland.

Hudson, T., J. Timbrook, and M. Rempe (eds). 1978. Tomol: Chumash Watercraft as Described in the Ethnographic Notes of John P. Harrington. Ballena Press/Santa Barbara Museum of Natural History, Santa Barbara, California.

Jennings, P. W. 1985. "HPLC-GPC Analysis of Asphalt Cements." In Proceedings of the Association of Asphalt Paving Technologist 54:635-646.

King, C. D. 1981. The Evolution of Chumash Society: A Comparative Study of Artifacts Used in Social System Maintenance in the Santa Barbara Channel Region Before A.D. 1804. Phd. Dissertation, Department of Anthropology, University of California, Davis, California.

Luey, J. K., and S. W. Li. 1992. Determination of the Biodegradation of Asphalt for the Hanford Grout Vaults. PNL-HGTP-91-0203-03, Pacific Northwest Laboratory, Richland, Washington.

Mill, T. D. 1990. "Oxidation and Photooxidation of Asphalt, Division of Petroleum Chemistry." American Chemical Society, Vol, 35, No, 3, Washington, D.C.

Moratto, M. J. 1984. California Archaeology. Academic Press, New York.

MRM Partnership. 1988. Bituminous and Asphaltic Membranes for Radioactive Waste Repositories on Land. DOE/RW/87.009, Report to the Department of the Environment, Bristol, England.

Muir, J. M. 1926. "Data on the Structure of Pre-Columbian Huastec Mounds in the Tampico Region." Journal of the Royal Anthropological Institute of Great Britain and ireland 56:231-238.

Nellensteyn, F. J. 1938. "Bitumen, Ein Verfestigungsmaterial fur Radioaktive Abfalle und Seine Historischen Analoga." Technischer Bericht NTB 83:11, Baden, Switzerland.

Periasamy, R., J. R. Newsome, A. L. Andrady, and D. S. Ensor. 1990. "Gas Permeability Measurements on Asphalt Using the Electrodynamic Balance." Symposium on Chemistry and Characterization of Asphalt, Division of Petroleum Chemistry 35:503-510, American Chemical Society, Washington, D.C. 
Petersen, J. C. 1986. "Quantitative Functional Group Analysis of Asphalt Using Differential Infrared Spectrometry and Selective Chemical Reactions-theory and Application."

Transportation Research Record 1096, Transportation Research Board, Washington, D.C.

Petersen, J. C. 1990. "Effects of Physicochemical Factors on Asphalt Aging." In Proceedings of the First Materials Engineering Congress Part - Serviceability and

Durability of Construction Materials, pp. 244-253. Denver, Colorado.

Petersen, J. C., E. K. Enseley, and F. A. Barbour. 1974. "Molecular Interactions of Asphalt in the Asphalt-aggregate Interface Region." Transportation Research Record 515, pp. 67-78.

Transportation Research Board, Washington, D.C.

Quddus, M. A., and F. Khan. 1990. "Factors Influencing Asphalt Oxidation." Fuel 69: 501-511.

Rogers, D. B. 1929. Prehistoric Man on the Santa Barbara Coast. Santa Barbara

Museum of Natural History, Santa Barbara, California.

Romine, R. A. 1992. Asphalt Handling Protocol. PNL-HGTP-93-06-01, Pacific Northwest Laboratory, Richland, Washington.

Steffen, H. 1984. "Report on Two-dimensional Stress-strain Behavior of Geomembranes With and Without Friction." In Proceedings of the International Conference on

Geomembranes. Denver, Colorado.

Strategic Highway Research Program (SHRP). 1992. Materials Reference Library: Asphalt Properties List, National Research Council, Washington, D.C.

Terrel, R. L. 1991. "Polymer-modified Hot-mix Asphalt for Environmental Liners." Hot Mix Asprialt Technology, Spring 1991:14-17.

Tuffour, Y. A., and I. Ishai. 1988. "Relating Asphalt Aging and Durability to Its Compositional Changes." Association of Asphalt Paving Technologist 57:117-124.

Tuffour, Y. A., and I. Ishai. 1990. "The Diffusion Model and Asphalt Age-hardening." Association of Asphalt Paving Technologist 59:73-92.

U.S. Department of Energy (DOE). 1987. Hanford Waste Management Plan, Richland Operations Office, Richland, Washington.

U.S. Department of Energy (DOE). 1988. Final Environmental Impact Statement for the Disposal of Hanford Defense High-Level, Transuranic, and Tank Wastes.

DOE/EIS-0113, Richland Operations Office, Richland, Washington.

U.S. Department of Energy (DOE). 1993. Report on Value Engineering Study of Permanent Isolation Surface Barrier and Warning Marker System Development Plan at the Hanford Site. DOE/RL/120074-8, Walla Walla District Army Corp of Engineers, Walla Walla, Washington. 
U.S. Environmental Protection Agency (EPA). 1982. Resource Conservation and Recovery Act (RCRA) Guidance Document: Landfill Design, Liner Systems and Final Cover.

PB87-157657, National Technical Information Service, Springfield, Virginia.

U.S. Environmental Protection Agency (EPA). 1990. Seminars--Design and Construction of RCRA/CERCLA Final Covers. Center for Environmental Research Information 90-55, Office of Research and Development, Washington, D.C.

Willey, G. R. 1966. An Introduction to American Archaeology: Vol I, North and Middle America. Prentice-Hall, Inc., Englewood Cliffs, New Jersey. 
PNL-9336

UC-702

\section{Distribution}

No. of

Copies

Offsite

12 DOE/Office of Scientific and Technical Information

C. S. Abrams

Argonne National Laboratory

P.O. Box 2528

Idaho Falls, ID 83401

3 Battelle Memorial Institute

Project Management Division

505 King Avenue

Columbus, $\mathrm{OH} 43201$

Attn: W. A. Carbeiner

W. S. Madia

Technical Library

D. E. Daniel

University of Texas

Dept. of Civil Eng.

Austin, TX $\mathbf{7 8 7 1 2}$

R. C. Letcher

U.S. Department of Energy

Morgantown Energy Technology

Center

P.O. Box 880

Morgantown, WV 26505

C. Massimino

U.S. Environmental Protection Agency

1200 Sixth Avenue

Seattle, WA 98101
No. of

Copies

J. Rensel

Washington State Department of Ecology

High-Level Waste Management

Mail Stop PV-11

Olympia, WA 98504

3 U.S. Department of Energy

785 DOE Place

Idaho Falls, ID 83402

Attn: O. D. Markham

R. C. Morris

T. E. Reynolds

2 U.S. Department of Energy Savannah River Operations

Office

P.O. Box A

Aiken, SC 29801

Attn: W. J. Brumley

D. Bruegennjohann

2 U.S. Environmental Protection Agency

Hanford Project Office

712 Swift, MS B5-01

Richland, WA 99352

Attn: D. A. Faulk

P. S. Innis

2 U.S. Geological Survey 1201 Pacific Ave., Suite 600

Tacoma, WA 98402

Attn: W. R. Bidlake

B. W. Drost

Dist.1 
No. of

Copies

2 Washington State Department of Ecology

7601 W. Clearwater, Suite 102

Kennewick, WA 99336

Attn: D. Teal

N. Uziemblo

3 Washington State Department of Ecology

Mail Stop PV-11

Olympia, WA 98504-8711

Attn: E. M. Carlin

C. Cline

R. B. Hibbard

2 Westinghouse Savannah River

Company

P.O. Box A

Aiken, SC 29801

Attn: S. R. McMullin

M. G. Serrato

Onsite

11 U.S. DOE. Richland Operations Office

G. J. Bracken, A4-02

J. J. Broderick, A7-27

R. D. Freeberg, A5-19

R. E. Gerton, A4-02

J. D. Goodenough, A5-19

A. C. Harris, A5-19

R. D. lzatt, $A 3-42$

P. M. Pak, A5-19

R. K. Stewart, A5-19

D. E. Trader, A5-90

DOE-RL Reading Room 1
No. of

Copies

2 U.S.Army Corps of Engineers

W. L. Greenwald, A5-20

J. H. Jacobson, A3-61

4 Kaiser Engineers Hanford

\section{Company}

S. D. Consort, E6-31

D. L. Fort, E6-50

L. A. Gladdis

R. 1. Watkins, E6-41

39 Westinghouse Hanford Company

M. R. Adams, H6-01

H. Babad, R2-78

R. J. Bliss, B3-04

M. A. Buckmaster, H6-03

J. W. Cammann, H4-14

R. A. Carlson, H6-03

C. C. Chamberlain, H6-28

A. P. Church, H6-28

H. D. Downey, H6-27

W. F. Heine, B3-63

C. E. Hodge, A5-56

R. W. Hookfin, H6-28

G. W. Jackson, H6-21

K. N. Jordan, H6-28

C. J. Kemp, H4-14

M. K. Korenko, B3-08

D. S. Landeen, H4-14

M. J. Lauterbach, H6-01

R. E. Lerch, B3-63

H. E. McGuire, B3-63

D. R. Meyers, S0-14

D. J. Newland, B1-58

K. L. Petersen, H4-14

R. W. Powell, H4-14

Dist.2 
No. of

Copies

Westinghouse Hanford Company (contd)

R. C. Roos, H6-04

M. R. Sackschewsky, H4-14

W. A. Skelly, H6-03

J. C. Sonnichsen, H4-14

J. A. Voogd, R4-03

G. G. Williamson, R4-01

N. R. Wing, H4-14

T. M. Wintczak, H6-27

D. E. Wood, H0-32

J. G. Woolard, H6-05

Publishing Services (3)

Environmental Data Management

Center (2)
No. of

Copies

38 Pacific Northwest Laboratory

L. L. Cadwell, P7-54

M. D. Campbell, K6-77

J. L. Downs, P7-54

M. J. Fayer, K6-77

D. Felmy, K6-77

M. G. Foley, K6-84

H. D. Freeman, P8-38 (5)

G. W. Gee, K6-77

M. J. Graham, K6-78

C. T. Kincaid, K6-77

R. R. Kirkham, K6-77

G. V. Last, K6-84

M. W. Ligotke, P7-54

S. O. Link, P7-54

T. L. Page, K1-37

J. C. Ritter, K6-77

M. L. Rockhold, K6-77

L. E. Rogers, P7-54

R. A. Romine, P8-38 (5)

M. A. Simmons, P7-54

R. L. Skaggs, K6-77

M. E. Thiede, K6-13

J. M. Thomas, P7-54

W. H. Walters, K6-06

Publishing Coordination

Technical Report Files (5)

Dist.3 

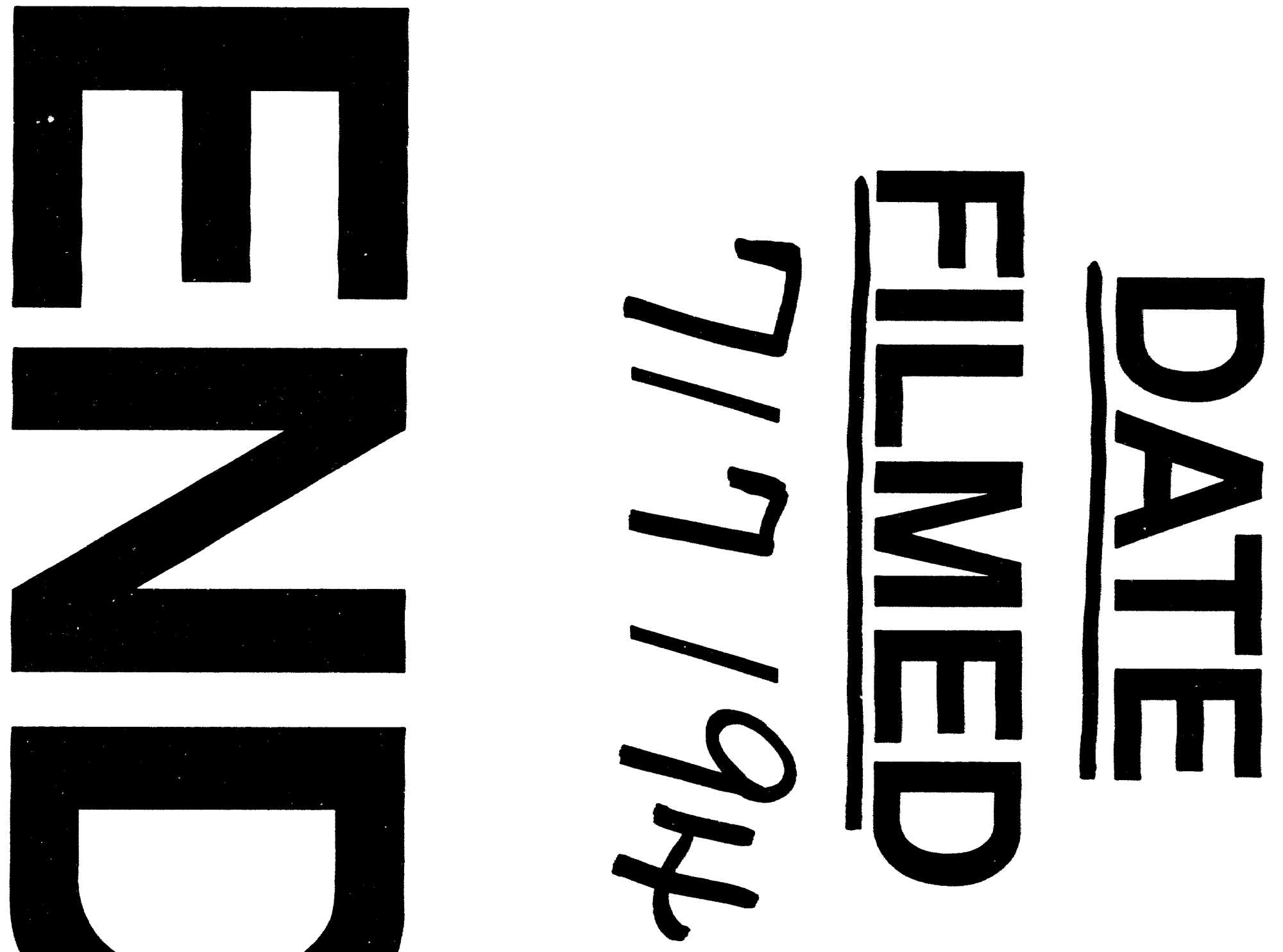
